\section{THE APPLICATION OF THE SVAP2 METHODOLOGY TO ASSESS ECOLOGICAL CONDITIONS OF LOTIC RIPARIAN AREA - CASE STUDY OF THE RADALJ RIVER (THE DRINA RIVER WATERSHEAD)}

UDC 502.51:551.435.17(497.11)

\begin{abstract}
The condition of riparian areas of surface watercourses is one of the key factors for the good ecological status of the rivers. Great importance is given to the research of the condition of riparian areas, as well as their revitalization, by the adoption of a series of international directives, the development of methodological procedures for the rapid assessment of the situation and the development of measures and techniques that help riparian areas to return to a more natural condition. This research was based on the possibility of applying the method of visual assessment of the situation. The Stream Visual Assessment Protocol 2 was used for the assessment of the quality and quantity of riparian areas on the Radalj River, a tributary of the Drina River, in the municipality of Mali Zvornik (Republic of Serbia. In order to evaluate riparian areas, five elements relating to the condition of the river beds and banks as well as qualitative and quantitative characteristics of the riparian areas were taken into account. The results showed that the riparian area at the monitored sites were in poor condition, and that according to the assessment and description, it is possible to draw preliminary conclusions on the additional studies and/or proposals for revitalizing techniques.
\end{abstract}

Key words: Riparian Areas Conditions, Radalj River, SVAP2

Received March 3, 2017 / Accepted May 17, 2017

Corresponding author: Sladjana Djordjevic

Belgrade University, Faculty of Agriculture, 6 Nemanjina Street, 11080 Zemun, Serbia

E-mail: sladjana.futura@gmail.com 


\section{INTRODUCTION}

The riparian area represents the transition between the aquatic and terrestrial ecosystems [1] and is a complex, dynamic ecosystem in which the further biological, physical and chemical processes take place [2-4]. Degradation of riparian areas affects the entire condition of the watercourse, that is, reflects the use of the land in coastal areas, pressures from pollutants and good or bad practices of resource management [5]. One of the key challenges of the 21 st century is to preserve biodiversity and water resources, and as riparian areas represent some of the most productive resources and the mutual interaction of watercourses and their flood zones and coastal areas [3], [6], [7], more attention is paid to the problem of degradation of riparian areas.

The importance of riparian area in ecological functioning of flowing water systems is widely recognized in European policies [8]: The Water Framework Directive recommends a systematic analysis of the structure of the riparian areas, as well as their involvement in the restoration and conservation into the programs of measures which are an integral part of plans for integrated river basin management; The Floods Directive (Directive 2007/60/EC) that seeks to prevent degradation and hydrological risks, The Directive on pesticides (Sustainable Use Directive 2009/128/EC), which aims to minimize the risk of indirect pollution, The Nitrates Directive (Council Directive 91/676/EEC), which aims to protect and prevent further excessive pollution of groundwater and drinking water by nitrates, largely caused by poor agricultural practices [9]; The Habitats Directive (Habitat Directive 92/43/EEC), which aims to preserve the European natural heritage.

By the ratification of The Water Framework Directive, and harmonizing it through the Water Act 2010/2012, Serbia has taken over the obligations of achieving good ecological status of water flows at the level of the river basin. The law defines the importance of riparian areas for ecological status of watercourses through the maintenance of protective facilities and large water troughs and the turnover of other activities related to water management [10].

The aim of this paper is to test the applicability of elements of The Stream Visual Assessment Protocol 2 methodology as a function of the preliminary assessment of the riparian areas condition and impact on the quality of the watercourses as a basis for further research or proposals for improvement.

\section{CASE STUDY}

The research was performed on the Radalj River that is one of the main tributaries of the river Drina. The length of its course is $15 \mathrm{~km}$, the catchment area $52 \mathrm{~km}^{2}$ and a maximum water flow rate of $125 \mathrm{~m}^{3} / \mathrm{s}$ [11].

According to the Regulations for defining water bodies of surface and underground waters [10], this stream is divided into 4 sections and belongs to Category I: Water body under the National jurisdiction. 


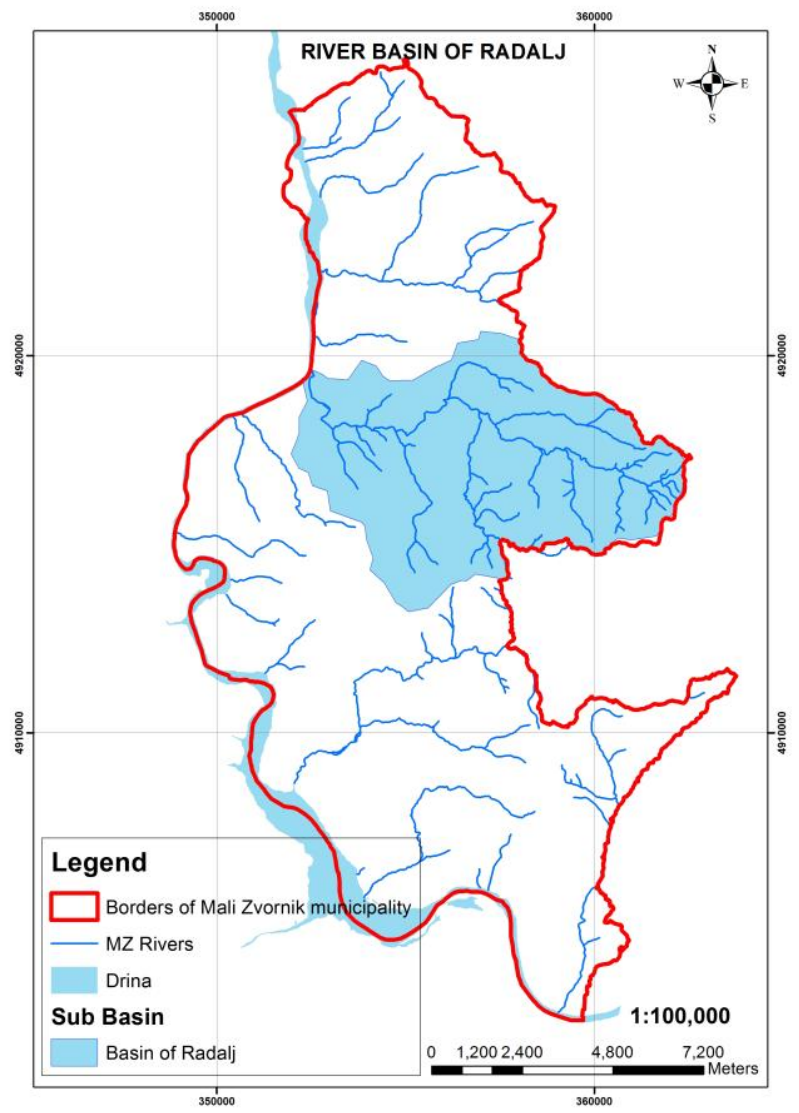

Fig. 1 The catchment area of the Radalj River

\section{MATERIAL AND METHODS}

The survey was conducted in July 2016 at SRR1 and SRR2, and in October 2016 at SRR3. The summer period is perhaps not the most favorable for field work with SVAP2 due to drought in the last decades. However, in 2016 there was abundant rainfall during May and June, so the vegetation was, due to sufficient amounts of rainfall, optimal for this type of assessment. In the field study was involved a multidisciplinary team made up of ecologists, environmental analysts, biologists, hydro geologists, geographers and risk managers.

For the purposes of this research were used five elements of The Stream Visual Assessment Protocol 2 (SVAP 2) methodology (Table 2), relating to the condition of the riverbed and the quality and quantity of riparian areas. SVAP2 has been developed by a working group for water resources in the Natural Resources Conservation Service within the United States Department of Agriculture and experts from University of Georgia (USA) [12], [13], the revised version of SVAP [14] with more comprehensive 
descriptions, that could be used by teams for water management planning, conservation and protection of the riverine environment, etc.

All available documentation and data on biodiversity of the areas and indigenous species, the interventions in the riverbed flow after floods in 2014, as well as the interviews with local residents about possible river flow changes, were researched.

The assessment was carried out at three pilot sites (Table 1, Figure 2) using the first five elements of SVAP2 relating to the watercourse riverbed geomorphology, hydrology and vegetation characteristics of the banks (Table 2).

Table 1 Pilot sites on the Radalj River

\begin{tabular}{|c|c|c|c|c|}
\hline \multirow[t]{2}{*}{ Site } & \multirow[t]{2}{*}{ Coordinates } & $\begin{array}{l}\text { Length of } \\
\text { assessment }\end{array}$ & $\begin{array}{l}\text { Bankfull } \\
\text { width }\end{array}$ & $\begin{array}{l}\text { Flood plain } \\
\text { area }\end{array}$ \\
\hline & & \multicolumn{3}{|c|}{ (unit - meters) } \\
\hline Site 1 (RRS1): 10,33 km upstream & $\begin{array}{l}\text { E } 19^{\circ} 13 ' 54.93^{\prime \prime} \\
\text { N } 44^{\circ} 23^{\prime} 50.35^{\prime \prime}\end{array}$ & 67,2 & 5.6 & 7,6 \\
\hline $\begin{array}{l}\text { Site } 2 \text { (RRS2): } 750 \mathrm{~m} \text { downstream } \\
\text { before the mouth into the Drina }\end{array}$ & $\begin{array}{l}\text { E } 19^{\circ} 8^{\prime} 52.26^{\prime \prime} \\
\text { N } 44^{\circ} 24^{\prime} 31.19^{\prime \prime}\end{array}$ & 81,6 & 6.8 & 5 \\
\hline Site 3 (RRS3): 6.05 km upstream & $\begin{array}{l}\text { E } 19^{\circ} 11 ' 32.62^{\prime \prime} \\
44^{\circ} 24^{\prime} 28.57^{\prime \prime}\end{array}$ & 73,2 & 6,1 & 14 \\
\hline
\end{tabular}

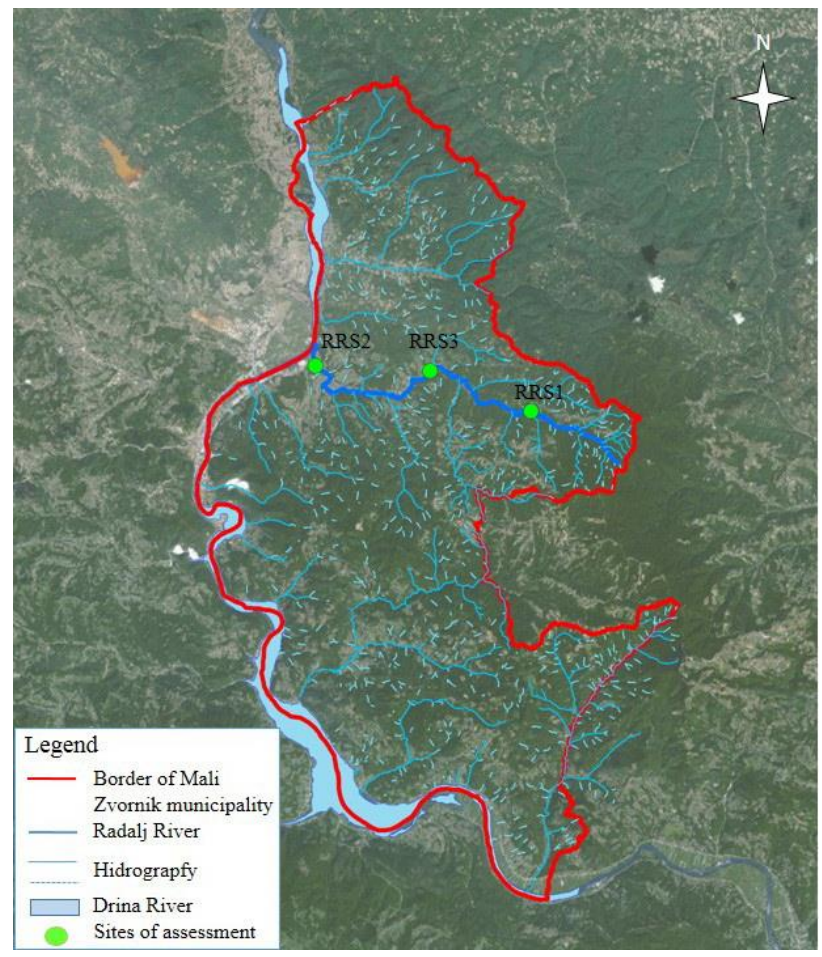

Fig. 2 Pilot sites where the research was conducted 
Table 2 Evaluated SVAP2 elements [12]

\begin{tabular}{ll}
\hline Evaluated elements & Why it is important \\
\hline Channel condition & $\begin{array}{l}\text { Channel condition represents a description of the geomorphic phase } \\
\text { of the channel as it adjusts its state relative to the floodplain. } \\
\text { The degree to which the hydrology and flow conditions differ from } \\
\text { natural, unregulated river/stream samples. }\end{array}$ \\
$\begin{array}{l}\text { Bank condition (left and } \\
\text { right bank) (left and right) }\end{array}$ & $\begin{array}{l}\text { Stable banks of watercourses are essential components of a } \\
\text { functional physical habitat and untouched biological communities. } \\
\text { Quantitative characteristics } \\
\text { of the riparian area of both } \\
\text { banks }\end{array}$ \\
$\begin{array}{l}\text { The quality of bank areas increases with latitude, equanimity and } \\
\text { linear distribution of its vegetation along the watercourses and it is } \\
\text { strongly influenced by hydrological characteristics of the } \\
\text { watercourse, as well as the state of the banks and the hills on the } \\
\text { mainland. }\end{array}$ \\
$\begin{array}{l}\text { Qualitative characteristics of } \\
\text { the riparian area of both } \\
\text { banks }\end{array}$ & $\begin{array}{l}\text { The width of the area under the vegetation is being assessed, from } \\
\text { the external borders of the aquatic river channel to the point where } \\
\text { the natural riparian vegetation ends and begins the use of land/land } \\
\text { cover for other purposes. }\end{array}$ \\
\hline
\end{tabular}

Descriptions for each element, or metric, identify the key features that are used to assign a score to that element; scores range from 10 (excellent) to 0 (poor). Elements: Bank condition, Quantitative and Qualitative characteristics of the riparian area has been evaluated separately: left and right riverbank and riverside. In the results, the average scores is shown.

\section{RESULTS AND DISCUSSION}

The assessed elements are shown in Tables 3-7. In addition to qualitative and quantitative characteristics of the coastal area, the condition of the riverbed, changes in hydrology and stability of banks, i.e. elements that need to be evaluated for their correlation with the condition of the immediate waterside were also assessed.

Table 3 Channel condition

\begin{tabular}{llc}
\hline Site & Description & $\begin{array}{c}\text { SVAP2 } \\
\text { score }\end{array}$ \\
\hline Site 1 (SRR1) & $\begin{array}{l}\text { Active wedging of the channel was recorded, as well as the fact } \\
\text { that the plant species are under stress, they die or fall into the } \\
\text { channel. The active channel is with a rare flooding or without } \\
\text { flooding. Small damages of the bank were also recorded. }\end{array}$ & 4 \\
Site 2 (SRR2) & $\begin{array}{l}\text { There were a lateral migration and erosion of the bank, and also } \\
\text { the deposition of sediments causes the channel to be very shallow } \\
\text { in some places and three to four islands on the channel were } \\
\text { noticed. }\end{array}$ & 3 \\
Site 3 (SRR3) & $\begin{array}{l}\text { Channel is aggrading, it is shallow in some places. One island } \\
\text { was noticed in the channel. Minimal lateral erosion was recorded. }\end{array}$ & 6 \\
\hline
\end{tabular}


Table 4 Hydrological alteration

\begin{tabular}{llc}
\hline Site & Description & $\begin{array}{c}\text { SVAP2 } \\
\text { score }\end{array}$ \\
\hline Site 1 (SRR1) & $\begin{array}{l}\text { It has been noted that higher flows occur once every three to five } \\
\text { years or less frequently, depending on the local natural flow } \\
\text { regime. The development in a floodplain or water control } \\
\text { structures may be present, but they do not substantially change } \\
\text { the natural flow regime. }\end{array}$ & 6 \\
Site 2 (SRR2) & $\begin{array}{l}\text { Higher flows occur once every three to five years or less frequently, } \\
\text { depending on the local natural flow regime. The development in a } \\
\text { floodplain or water control structures may be present, but they do } \\
\text { not substantially change the natural flow regime. }\end{array}$ & 7 \\
& $\begin{array}{l}\text { The left bank is structured, as opposed to the right bank. Concrete } \\
\text { elements were noticed in the riverbed. The natural flow regime is } \\
\text { prevailing. }\end{array}$ & 7 \\
\hline
\end{tabular}

Table 5 Bank condition

\begin{tabular}{|c|c|c|}
\hline Site & Description & SVAP2 score \\
\hline Site 1 (SRR1) & $\begin{array}{l}\text { The banks are moderately stable, protected by the roots } \\
\text { of natural vegetation, trees, rocks, or a combination of } \\
\text { materials. A limited number of structures exists on the } \\
\text { coast. Erosion and collapse of the bank are present; } \\
\text { parts with the re-establishment of vegetation are } \\
\text { noticed. The use of the bank for recreation and/or } \\
\text { grazing at this location does not adversely affect the } \\
\text { state of the bank. }\end{array}$ & $\begin{array}{c}\text { Left bank }=7 \\
\text { Right bank }=5\end{array}$ \\
\hline Site 2 (SRR2) & $\begin{array}{l}\text { The banks are moderately unstable, protection of the } \\
\text { banks by the roots of natural trees and vegetation is } \\
\text { insufficient. Fabricated structures can be found on more } \\
\text { than half of the stream flows or on the entire bank. The } \\
\text { instability of the bank is affected by the use of the bank } \\
\text { for cattle grazing but also various forms of recreation. }\end{array}$ & $\begin{array}{c}\text { Left bank }=4.5 \\
\text { Right bank }=5.5\end{array}$ \\
\hline Site 3 (SRR3) & $\begin{array}{l}\text { Left bank has fabricated structures. The erosion is } \\
\text { noticed in the concave bank. On meander, the flow } \\
\text { slows down because it expands, and after meander, the } \\
\text { flow accelerates because of the presence of waterfalls. } \\
\text { The vegetation is not strong enough to contribute to the } \\
\text { stability of the bank. Right bank has fabricated } \\
\text { structures and there is a drift due to a nearby road in one } \\
\text { part, while in the second part the bank is natural, there } \\
\text { is bushy and woody vegetation. There is no evidence of } \\
\text { large erosion. }\end{array}$ & $\begin{array}{c}\text { Left bank }=6 \\
\text { Right bank }=7\end{array}$ \\
\hline
\end{tabular}


Table 6 Quantitative characteristics of the riparian area of both banks

\begin{tabular}{|c|c|c|}
\hline Site & Description & SVAP2 score \\
\hline Site 1 (SRR1) & $\begin{array}{l}\text { It is indicated that the natural plant vegetation extends } \\
\text { over a width of at least } 1 / 2 \text { of the bank or more than } 1 / 2 \\
\text { to } 2 / 3 \text { of floodplain soil active zone and for the most part } \\
\text { it borders the riparian areas. The lack of vegetation does } \\
\text { not exceed } 10 \% \text { of the estimated length of the } \\
\text { watercourse. }\end{array}$ & $\begin{array}{l}\text { Left bank }=7 \\
\text { Right bank }=6\end{array}$ \\
\hline Site 2 (SRR2) & $\begin{array}{l}\text { Natural plant vegetation extends over a width of at least } \\
1 / 2 \text { of the bank or more of at least } 1 / 2 \text { of floodplain soil } \\
\text { active zone; the absence of vegetation does not exceed } \\
30 \% \text { of the estimated length of the watercourse. }\end{array}$ & $\begin{array}{l}\text { Left bank }=4 \\
\text { Right bank }=6\end{array}$ \\
\hline Site 3 (SRR3) & $\begin{array}{l}\text { The vegetation stretches along the bank. On average } 10 \text { - } \\
20 \% \text { of the area is without vegetation. }\end{array}$ & $\begin{array}{l}\text { Left bank }=8 \\
\text { Right bank }=7\end{array}$ \\
\hline
\end{tabular}

Table 7 Qualitative characteristics of the riparian area of both banks

\begin{tabular}{llc}
\hline Site & Description & SVAP2 score \\
\hline Site 1 (SRR1) & $\begin{array}{l}\text { It is indicated that the composition, density and age } \\
\text { structure of the natural and diverse riparian vegetation } \\
\text { are appropriate to this habitat. Invasive species are } \\
\text { present in a small number }(20 \%)\end{array}$ & $\begin{array}{c}\text { Left bank }=8 \\
\text { Right bank }=5,5\end{array}$ \\
& $\begin{array}{l}\text { Natural vegetation is compromised, i.e. violated; } \\
\text { Site 2 (SRR2) }\end{array}$ & $\begin{array}{c}\text { Left bank }=3,5 \\
\text { Site 3 (SRR3) }\end{array}$ \\
& $\begin{array}{l}\text { There is a large number of invasive species. The right } \\
\text { bank is dominated by annuals, while on the left bank is } \\
\text { present higher percentage of perennial plants. }\end{array}$ & $\begin{array}{c}\text { Right bank }=4,5 \\
\text { Left bank }=6\end{array}$ \\
& Right bank $=6$ \\
\hline
\end{tabular}

Based on the conducted assessment, it was noticed that the lower part of the flow (site 2 ), evaluated with mark 4,7- poor condition, has more degradation forms and factors than the upper part of the flow (site 1, which has slightly more favorable conditions, but not satisfying and evaluated with overall mark 5.7), while in the central part of the flow (site 3 ) the situation is the most favorable in relation to the previous sites and evaluated with mark 6,6 which is a favorable condition (however, with the presence of a large number of invasive species that can further influence on changes in the biodiversity structure), when it comes to potential and current condition of riparian areas of the flow of preliminarily investigated sites. Table 8 shows the results obtained by SVAP 2 classification.

Table 8 SVAP2 score and Classification for pilot sites

\begin{tabular}{ccccc}
\hline SVAP2 Score & $\begin{array}{c}\text { Classification } \\
\text { (condition) }\end{array}$ & SRR1 & $\begin{array}{c}\text { Sites } \\
\text { SRR2 }\end{array}$ & SRR3 \\
\hline $0-2.9$ & Severely degraded & & & \\
$3-4.9$ & Poor & 5.7 & 4.7 & 6.6 \\
$5-6.9$ & Fair & 5.7 & & \\
$7-8.9$ & Good & & & \\
$9-10$ & Excellent & & & \\
\hline
\end{tabular}


The reasons for degradation of riparian areas and the watercourses are urbanization and interventions in the riverbed after the torrential discharging and flooding in 2014, which all together contributed to the riverbed and the river flow, riparian area, plant and aquatic species. In the case of the Radalj River, the results indicate that the riparian area has significantly been degraded in certain parts of the flow and that there is a risk of further degradation processes that will affect the entire ecological status of rivers.

The access to a visual assessment of the condition, i.e. elements that directly or indirectly may give a preliminary assessment of the condition of riparian areas, gives the first input data necessary for further steps in the decision-making process of revitalization of coastal areas, as well as the improvement of agricultural practices in the immediate bank area.

\section{CONCLUSION}

In the pilot sites on the Radalj River, one of the main tributaries of the Drina, by evaluation of 5 from 16 SVAP2 elements, a number of problems were diagnosed: fragile banks, vegetation that cannot stabilize the bank, invasive species in relation to the potential and poor functional status of the coastal ecosystem. The used methodological approach is primarily in evaluating the condition of the watercourse, but it can give a first assessment of riparian areas and impact on the stability of the banks and the status of the watercourse. In the basin of the river Drina, on torrential flows, as is the river Radalj, many interventions were carried out in the stream's channel which, among other degradation factors significantly contributed to insufficiently good status. Field data indicate that this method can treat individual sites, or zones, with additional studies, in order to design measures of techniques for the revitalization of the zones which are critically devastated. To determine the status of the riparian area of the entire course, it is necessary to make assessments on several sites separately or in combination with other methods.

In Serbia, the issue of riverside degradation and the possibility for the improvement of riparian areas that are habitat for many species have not been given significant attention so far.

In the end, we can conclude that apart from agriculture and urbanization, there are other factors which influenced degradation of watercourses and their riparian areas in the Drina River basin, more specifically undefined boundaries of water lands pastures or agricultural households.

Acknowledgement: This work is the result of the pilot project: "Pilot action "Value Drina", supported by the US Agency for Environmental Protection (US EPA) within the project "Capacity building of local communities for sustainable developments in international river basins, such as watersheds Drim and Drina" (CRESSIDA), and implemented by the Regional Environmental Center (REC) for Central and Southeast Europe. 


\section{REFERENCES}

1. Water and River Commission, Advisory notes for Land Managers on River and Wetland Restoration, WN12, 2000.

2. Anderson E. W., "Riparian Area Definition-A Viewpoint," Rangelands, vol. 9, no. 2, pp. 70-74, 1987. [Online]. Available: http://dx.doi.org/10.2458/azu_rangelands_v9i2_70

3. T. Svejcar, "Riparian Zones: 1) What are they and how do they work?", Rangelands, vol. 19, no. 4, pp. 4-7, 1997. [Online]. Available: http://oregonstate.edu/dept/eoarc/sites/default/files/publication/411.pdf

4. National Research Council, Riparian areas: Functions and strategies for management. National Academy Press. Washington, DC; 2002.

5. Krpic T., Djordjevic S., Stankovic M., Cvetkovic D., Ninkovic M., Pejic D., Katic B., (2016), Procena ekološkog statusa riparijalnog područja i preporuke za revitalizaciju - studija slučaja Radaljska reka, (Zbornik radova), V Nacionalna konferencija sa međunarodnim učeśćem "Inovacioni modeli ekosistemskog inženjerstva “, Beograd, 08. november 2016, pp. 96-104. ISBN: 978-86-86859-54-9

6. Brinson M. M., et al., Riparian Ecosystems: Their Ecology and Status. U.S. Department of the Interior, Fish and Wildlife Service, Kearneysville, West Virginia, 1981.

7. Cushing B. and J. Allen, (2001), Streams: their ecology and life, Academic Press, San Diego, CA

8. Djordjević-Miloševic S., Djordjevic S., Cvetkovic D. (2016), Managing Riparian Areas in Small Rivers using an Integrated Process, (Published Conference Proceedings style), First National Conference with International Participation, Ecological and Social Innovations: Challenges Of Applied Sciences, Belgrade, June 3-4, pp. 96-102.

9. Foged H. L., Djordjevic-Milosevic S., The best agricultural practices - what is it, how that can be applied, UNDP/GEF DRP - CarlBro, Denmark, 2006.

10. Water Act, Official Gazette of RS No.30/10 and 93/12

11. Djordjevic S. et al, (2016), Six Decades of Mali Zvornik Municipality, Monograph, Edited by Sladjana Djordjevic, ISBN:978-86-907361-2-6, Mali Zvornik Municipality.

12. USDA NRCS, Stream Visual Assessment Protocol Version 2, in National Biology Handbook Subpart B-Conservation Planning, 2009, 75 pp.

13. Boyer K., et al, Stream Visual Assessment Protocol Version 2, in National Biology Handbook, Subpart $B$-Conservation Planning, United States Department of Agriculture Natural Resources Conservation Service, 2009

14. United States Department of Agriculture (USDA), Stream Visual Assessment Protocol (No. NWCC-TN99-1). Portland, Oregon: National Water and Climate Center, 1998.

\section{PRIMENA SVAP2 ZA PROCENU EKOLOŠKOG STANJA RIPARIJALNIH ZONA LOTIČKOG PODRUČJA - STUDIJA SLUČAJA RADALJSKA REKA (SLIV REKE DRINE)}

Stanje riparijalnih oblasti površinskih tokova predstavlja jedan od ključnih faktora za dobar ekološki status samog vodotoka. Istraživanjima stanja riparijalnih oblasti, kao i njihovoj revitalizaciji pridaje se veliki značaj donošenjem niza međunarodnih direktiva, razvojem metodoloških postupaka za brzu procenu stanja, kao i razvojem mera i tehnika kojima se riparijalno područje vraća u što prirodnije stanje. Istraživanje je bazirano na mogućnosti primene vizuelnih metoda procene stanja. Korišćen je The Stream Visual Assessment Protocol 2 za ocenu kvaliteta i kvantiteta riparijalnih područja na Radaljskoj reci, pritoci reke Drine, u opštini Mali Zvornik (Republika Srbija). Za riparijalna područja uzete su ocene pet elemenata koji se odnose na stanje rečnog korita $i$ obala, $i$ kvalitativne $i$ kvantitativne karakteristike riparijalnih područja. Rezultati su pokazali da je riparijalno područje u slabom stanju na posmatranim lokacijama, $i$ da prema oceni $i$ deskripciji se mogu izvesti preliminarni zaključci o potrebnim dodatnim istraživanjima i/ili predlozima tehnika za revitalizaciju.

Ključne reči: Stanje riparijalnih područja, Radaljska reka, SVAP2 